\title{
Characteristics of cannabis users seeking treatment in São Paulo, Brazil
}

\author{
Flávia Serebrenic Jungerman ${ }^{1}$ and Ronaldo Laranjeira ${ }^{2}$
}

Suggested citation Jungerman FS, Laranjeira R. Characteristics of cannabis users seeking treatment in São Paulo, Brazil. Rev Panam Salud Publica. 2008;23(6):384-93.

ABSTRACT Thjectives. This article describes a sample of 160 adults selected to participate in a random-
ized controlled trial conducted at a specialized outpatient clinic for cannabis users in Brazil. It
correlates consumption with several measures of marijuana use, comparing it with other samples.
Methods. Instruments used were the Composite International Diagnostic Interview (CIDI)
and Wender Utah Rating Scale for screening and demographic data interviews, and the ASI,
time-line follow back (TLFB), Marijuana Withdrawal and Marijuana Problem Scales, and Di-
agnostic and Statistical Manual of Mental Disorders (DSM-III-R) Checklist for cannabis de-
pendence.
Results. Participants in the study were mostly single, white men; their mean age was 32.3
years. They had a mean of 15.6 years of formal education and $61.6 \%$ worked. The cohort
started using marijuana at a mean age of 16.5 years and developed daily use by a mean age of
21 years. Subjects in the sample had used marijuana for a mean of 15 years. They used it for
92.2\% of the 90 days prior to the interview and smoked a mean of 1.99 marijuana cigarettes
per day during this period. Individuals in the group had experimented with other drugs, espe-
cially cocaine.
Conclusions. Marijuana users in this sample matched the profiles of those investigated
elsewhere, although they reported fewer symptoms of dependence. Marijuana users should be
considered independently in substance abuse programs, because they require specific attention
and treatment. Broader epidemiological studies should be conducted to determine the extent of
marijuana use within the Brazilian population.

Key words Marijuana, marijuana abuse, marijuana dependence, substance abuse treatment centers, Brazil.

Cannabis is the most widely abused illicit drug in the world $(1,2)$. According to data collected for 2005 and 2006, more than $3.8 \%$ of the world's popula-

1 Independent research scientist, São Paulo, Brazil. Send correspondence to F.S. Jungerman, Rua Pascoal Vita 342, São Paulo 05445-000, Brazil; email: fla.de@uol.com.br.

2 Alcohol and Drug Research Unit (UNIAD), São Paulo Federal University, São Paulo, Brazil. tion has used cannabis (3). There is considerable experimentation with cannabis among teenagers in Australia, Europe, and the United States (2). According to a survey carried out in 2006 in the United States, 39.8\% of the population (12 years old and above) had experimented with cannabis; $10.3 \%$ of those surveyed had used it in the year prior and 6.0\% had used it in the month prior to the inter- view (4). Approximately $9 \%$ of those who had used marijuana had met criteria for dependence at some point (5, $6)$. For those who had used the drug more than a few times, the dependence risk rose to $20 \%-30 \%$ (7). The rate of marijuana dependence in the U.S. is estimated to be greater than $7 \%$ among adult users (8), compared with $12 \%$ for cocaine and $5 \%$ for alcohol. A recent study in New Zealand shows 
that by the age of 21 , over $10 \%$ of a sample of 1265 people met criteria for cannabis dependence (9).

In Brazil, marijuana is the most commonly used illicit drug after volatile solvents, but its use is lower than in other countries. According to a survey with students from middle and high schools in 10 Brazilian cities, marijuana use in life rose from $2.8 \%$ in 1987 to $5.9 \%$ in 1997 (10). In 2004, the survey included 27 cities and found that lifetime marijuana use was $5.9 \%$, placing it just below that of alcohol, tobacco, and solvents (11). Use in Brazil was lower than that of several other South American countries: studies conducted for similar age groups between 2003 and 2006 reported that lifetime marijuana use was $21.6 \%$ in Chile (12), $18.6 \%$ in Ecuador, $12.5 \%$ in Uruguay, $7.2 \%$ in Guyana, and $6.9 \%$ in both Panama and Nicaragua. The Brazilian rate was higher than in Paraguay $(4.3 \%)$ and Venezuela (1.0\%) (13). For youth between 15 and 16 years old, lifetime use in Brazil was 7.5\%, much lower than for the same ages in France and the United Kingdom (each with $38.0 \%)$, the United States (35.1\%), Belgium $(32.0 \%)$, Spain $(30.0 \%)$, the Netherlands $(28.0 \%)$, and Italy and Germany (each with $27.0 \%)(14,15)$.

In terms of rate of frequent use (i.e., used 6 or more times in the last 30 days), in Brazil there was a decrease from $0.8 \%$ in 1997 to $0.7 \%$ in 2004 . Heavy use (i.e., 20 or more times in the last 30 days) remained at $0.5 \%$ in 1997 (11). Compared with other drugs, cannabis ranks just under solvents for heavy use.

In a 2001 household survey of people between 12 and 65 years old, conducted in 107 Brazilian cities, reported lifetime marijuana use was $6.9 \%$ (16), very similar to rates in Colombia $(5.4 \%)$ and Germany $(4.2 \%)$, but significantly lower than rates in the United States $(34.2 \%)$, the United Kingdom (25.0\%), Denmark (24.3\%), Spain $(19.8 \%)$, Chile $(19.7 \%)$, the Netherlands $(19.1 \%)$, Greece $(13.1 \%)$, and Sweden $(13.0 \%)(3,12,14,17)$. One percent of respondents in the Brazilian household survey reported symptoms of marijuana dependence (16).
Although the use of cannabis is widespread, little research has focused on the treatment of marijuana users because of the mistaken belief that cannabis causes no harm $(18,19)$. However, studies have been carried out recently showing negative effects of the drug, such as: subjects starting to use at an earlier age, the relationship between cannabis use and psychosis, neuropsychological dysfunction, risk of consumption during pregnancy, and negative respiratory effects (20).

The number of people requesting treatment for cannabis dependence is rising, particularly in the United States and Australia, where from 1993 to 1999 , the number in treatment doubled (6). Studies have shown that $20 \%$ of clients entering addiction services reported cannabis as a problem substance (21-23).

While marijuana use is a concern of health professionals, particularly in the United States, Australia, and New Zealand, only a few clinical population studies have been undertaken (18). The profile of the samples studied in such trials is very different from the general population. Compared with the populations in the United States and Australia, cannabis users who seek treatment in Brazil tend to be older, having a mean age of 32 years, and are predominantly male, white, single, have some education, and have an occupation. With regard to cannabis use, the United States population follows a pattern of onset at age 16, where problematic use begins three years later (24-27). In Australian samples, subjects tend to begin at an earlier age (around 15 years old) with the onset of problematic use at 18 years old (28-30). However, all U.S. and Australian subjects reported several years of very heavy use (more than once a day for 15 years) and many problems associated with their marijuana use (average of 8.5 ) as well as dependence symptoms (average of 6.16), the most common of which were "unsuccessful attempts to quit or cut down" (24-27).

Although the epidemiologic data on cannabis use and abuse are limited in Brazil, they do indicate that marijuana is a problem for the Brazilian popula- tion. In Brazil, little attention has been given to marijuana users, possibly for reasons mentioned above, but basically because the harms wrought are not immediately perceived. The major challenge in treating marijuana users is that the impact of adverse effects only becomes evident after prolonged and frequent use (19). Given that it is difficult for patients to realize the drug is doing them harm, the belief that marijuana is a "soft" drug is still held by some health professionals.

In 2000, an out-patient clinic was opened in São Paulo, Brazil's largest city, exclusively to treat marijuana users, representing the only such specialized service in the country. The researchers conducted a randomized controlled trial specific to marijuana users, testing a brief psychological intervention.

This article describes the sample selected in terms of drug abuse patterns, particularly of cannabis, and related problems and symptoms, and compares the sample to those described in the literature.

\section{MATERIALS AND METHODS}

The cannabis users' treatment study was conducted at São Paulo Federal University's out-patient clinic which specializes in the treatment of alcohol and drug users. The clinic comprises different out-patient clinics, one of which is for marijuana users over 18 years of age. After two years of providing treatment for this population, the team responsible for the clinic conducted the trial in order to test a brief individual intervention described by Jungerman (31).

\section{Participants}

Participants were recruited between September 2003 and October 2004. Of those who came for an interview, $60.5 \%$ responded to a newspaper advertisement, $17 \%$ had seen a report on a television program, $8 \%$ had been informed about the program by a friend or family member, $6.5 \%$ had read an 
announcement on the clinic Web site, and the remainder came in response to flyers distributed at metro stations and university entrance gates, or as a result of radio messages about the program. All of the announcements invited marijuana users who were at least 18 years old and who wished to quit smoking marijuana and required help, to contact the outpatient clinic.

\section{Inclusion/exclusion criteria}

There were 277 respondents to the announcements. They were invited for a personal interview that consisted of a brief screening to determine whether they met inclusion criteria. Interviewees provided basic information (age, permanent address, and contact information) along with a history of their use of cannabis and of other drugs in the last three months. On successful completion of the screening, they underwent the Composite International Diagnostic Interview (CIDI) (32) and Wender Utah Rating Scale (33). Participants were eligible for the study if they were at least 18 years old, had smoked marijuana on at least 40 occasions in the last 90 days (i.e., 3 times per week), had no psychiatric illness, no dependence on any other drug, and were not undergoing any other treatment for cannabis use (attendance at Narcotics Anonymous meetings was not counted as treatment). The results of the CIDI were used to exclude psychiatric disorders and other drug dependence.

Of the 277 individuals interviewed, $186(67 \%)$ were eligible. The main reasons for exclusion were: $31 \%$ had used low levels of cannabis in the last 90 days, $11 \%$ met criteria for depression, $12 \%$ were undergoing other treatment for cannabis use, $10 \%$ fulfilled criteria either for abuse or dependence on Cocaine, $11 \%$ met criteria for other psychiatric illnesses (such as attention deficit hyperactivity disorder and generalized anxiety disorder), $7 \%$ met criteria either for abuse or dependence on alcohol, and $7 \%$ were polydrug users. For $77 \%$ of the sample, the main reason given for seeking treatment was the desire to quit smoking marijuana.
Of the 186 eligible subjects, 13 failed to come in for the baseline interview, giving an initial sample of 173 . For the purpose of this study, the sample comprised 160 individuals.

The project was approved by the Ethical Committee of the São Paulo Federal University.

\section{Assessment procedures}

After the initial screening, subjects who were determined to be eligible were invited for a baseline interview. They were first presented with a consent form and received explanations on all the research procedures, including randomization. Once they had signed the consent form, they took part in a structured interview that included a demographic data questionnaire with a history of their drug use. A time-line follow back (TLFB) (34) was used to gather a history of marijuana use, as well as to check in detail the pattern and frequency of consumption of marijuana and any other drugs. The number and size of joints (marijuana cigarettes) smoked over the last 90 days were recorded on a calendar that divided each day into quarters (12 a.m.-6 a.m.; 6 a.m.-12 p.m.; 12 p.m. -6 p.m.; 6 p.m.-12 a.m.). Number of joints consumed, the number of days participants smoked per week, as well as the number of quarters of days participants smoked per day were calculated. The nine Diagnostic and Statistical Manual of Mental Disorders (DSM-III-R) Checklist criteria for cannabis dependence were also used (including two for tolerance symptoms and two for abstinence symptoms) (35).

Subjects also completed a series of self-report questionnaires to measure secondary outcomes including the Marijuana Withdrawal Scale (MWS) $(36,37)$, to check the most common symptoms from their most recent period of abstinence, and the Marijuana Problem Scale (MPS) (26), which is a 19item scale used to measure recent problems associated with marijuana use.

The subjects randomly took urine tests that checked only for tetrahydrocannibol (THC).

\section{Data analysis}

Quantitative variables were expressed as means, standard deviations, minimums, and maximums. Categorical variables were summarized as absolute and relative frequencies. Pearson's correlation coefficient and ANOVA were used to evaluate the associations between the use of marijuana and other variables. All the analyses were performed using SPSS statistical software, version 15.0 (SPSS Inc, Chicago, Illinois, U.S.A.).

\section{RESULTS}

The sample studied comprised 160 marijuana users. Table 1 shows the demographic data from the sample. The mean age was 32.32 years old $(\mathrm{SD}=$ 8.37; range 18-59 years). Subjects were mainly male, white, and single. They had a mean of 15.64 years of schooling $(\mathrm{SD}=3.67$; range 5-34 years). Most subjects worked $(61.6 \%)$ and number both worked and studied (16.3\%). The majority of the subjects lived in their own homes.

Information regarding the sample's marijuana use is shown in Tables 2 and 3 . The mean age at first use was 16.44 years old $(\mathrm{SD}=3.67$; range $8-35$ years) and the mean age at onset of daily use was 21.08 years old (SD = 5.85; range 13-55). Mean years of use was 16.01 ( $\mathrm{SD}=8.23$; range 3-46). Marijuana consumption in the 90 days prior to the baseline interview was recorded. The percentage of days smoked in that period was $92.19 \%$, the mean number of joints smoked per day was 1.99 , and the mean number of quarters (6-hour periods) per day that the subjects smoked marijuana was 2.05. All but one of the subjects underwent urine testing, and $100 \%$ of those tested were positive for THC.

Table 3 shows circumstances of first experimentation and patterns of use. Most subjects first tried marijuana with friends $(78.1 \%)$, on the street $(37.5 \%)$, or at home $(28 \%)$. The most important factors that motivated subjects to experiment were "curiosity" $(62.5 \%)$, followed by social pressure 
TABLE 1. Demographic data for sample of adult cannabis users $(n=160)$, Brazil, September 2003 to October 2004

\begin{tabular}{lrc}
\hline \multicolumn{1}{c}{ Category } & No. & $\begin{array}{c}\text { Percentage } \\
\text { of sample }\end{array}$ \\
\hline Gender & & \\
Male & 128 & 80.0 \\
$\quad$ Female & 32 & 20.0 \\
Ethnicity & & \\
$\quad$ White & 143 & 89.4 \\
$\quad$ Black & 17 & 10.6 \\
Marital status & & \\
$\quad$ Single & 103 & 64.4 \\
Married/live together & 40 & 25.0 \\
$\quad$ Divorced/separated & 17 & 10.6 \\
Residence & & \\
$\quad$ Own & 95 & 59.4 \\
Rent & 56 & 35.0 \\
$\quad$ Borrow/Squat & 9 & 5.6 \\
Religion & & \\
$\quad$ None & 53 & 33.1 \\
Catholic & 63 & 39.4 \\
$\quad$ Spiritualist & 22 & 13.8 \\
Other & 22 & 13.8 \\
Occupation & & \\
$\quad$ Employed & 99 & 61.6 \\
Works and studies & 26 & 16.4 \\
Unemployed & 21 & 13.2 \\
Student & 14 & 8.8 \\
\hline
\end{tabular}

$(28.1 \%)$. The major factor that led subjects to continue using marijuana was "pleasure" or "good sensations" $(61.9 \%)$, followed by pressure of friends $(16.3 \%)$ These were the same reasons given for increased use $(68.8 \%$

All but two subjects $(98.8 \%)$ used marijuana in joints. When asked about frequency of use in the last year, $50.0 \%$ reported they had used more than once a day, and $34.4 \%$ reported they smoked one time daily. Most users (74.4\%) smoked alone, and 51.3\% and $7.5 \%$, respectively).

smoked in "puffs" (that is, they lit and relit the same joint), whereas $38.8 \%$ smoked whole joints. For $88.1 \%$ of the sample, the preferred time of day for use was the third quarter (from 6 p.m. to 12 a.m.).

An attempt was made to measure the size of the joint smoked by associating the grams of marijuana it contained, but smokers had difficulty providing this information. Consequently, a scale of "thin," "medium" (cigarette size), and "large" joint size was adopted, where the medium size weighed approximately 1 gram. Nearly half $(47.5 \%)$ of the sample smoked thin, and $40.6 \%$ smoked medium-sized joints.

Fifty-nine percent of the subjects spent up to 70 Brazilian reais (US\$20) per month on marijuana. Most bought their own marijuana (89.9\%); purchases were made "from a friend or acquaintance" (42.5\%), at a drug hangout $(33.1 \%)$, from a drug dealer $(9.4 \%)$, or ordered by telephone and delivered $(10.6 \%)$

Table 4 shows the history of cessation for the subjects. Most (76.9\%) had previously stopped or attempted to stop smoking marijuana within the last year and had done so alone. These attempts were made alone because $95.0 \%$ of subjects had never received treatment for their marijuana problem. Reduction in marijuana consumption had been attempted by $73.1 \%$ of the sample, and different approaches were reported: $53.1 \%$ said they had reduced the number of joints smoked per day; $33.5 \%$ reduced the number of times they smoked each day; $25.6 \%$ cut down on the number of days in the week they smoked; and $19.1 \%$

TABLE 2. Characteristics of marijuana use reported by sample of adults ( $n=160$ ) seeking treatment, Brazil, September 2003 to October 2004

\begin{tabular}{lcccc}
\hline \multicolumn{1}{c}{ Characteristic } & Mean & $\begin{array}{c}\text { Standard } \\
\text { deviation }\end{array}$ & Minimum & Maximum \\
\hline Age at first use & 16.44 & 3.65 & 8 & 35 \\
Age at beginning of daily use & 21.08 & 5.85 & 13 & 55 \\
$\begin{array}{l}\text { No. of years of use } \\
\text { No. of joints smoked per day over }\end{array}$ & 16.01 & 8.23 & 3 & 46 \\
$\quad \begin{array}{l}\text { the last 90 days } \\
\quad \text { No. of quarters (6-hour periods) }\end{array}$ & 1.99 & 2.08 & .04 & 11.82 \\
$\quad$ smoked per day over the last 90 days & 2.05 & 1.99 & 0.28 & 4.0 \\
\hline
\end{tabular}

changed the hours (six-hour periods) that they smoked in the day.

When asked how much they knew about marijuana, $43.8 \%$ of the sample stated they knew "something." The majority $(92.5 \%)$ wanted to know more, mainly about its adverse effects.

The mean number of dependence symptoms was $5.48(\mathrm{SD}=2.14)$ out of a total of 9. These results were lower than those reported in other studies $(27,29)$. Table 5 shows the most frequently reported symptoms, with the main one being "unsuccessful attempts to quit or cut down," mirroring other studies but with a lower percentage (83.7\% in the present study versus $96 \%$ reported in Stephens et al.[27]). If we consider that dependence satisfies at least three of the seven symptoms, $88.7 \%$ of the sample met criteria for dependence. The two main variables that measure consumption are: percentage of days smoked and mean number of joints smoked per day in the last 90 days. The correlation between the mean number of symptoms and the two variables measuring consumption was statistically significant $(\mathrm{r}=0.322$, $P<0.001$ for mean number of joints smoked and $\mathrm{r}=0.350, P<0.001$ for percentage of days smoked).

Table 5 also shows associations between the two main variables measuring consumption (percentage of days smoked and mean number of joints smoked per day in the last 90 days) and each of the nine symptoms of the dependence syndrome. For both measures of consumption there was a statistically significant correlation for the two tolerance symptoms and for "considerable time spent buying, using, or recovering from the effects." Moreover, there was a partially statistically significant correlation (i.e., for just one of the two measures: either percentage of days smoked or mean number of joints smoked per day) for the following: two symptoms of abstinence, "using for a longer period of time or more than intended," "using takes up the time normally spent on other important activities," "using despite persistent or recurrent psychological or physical problems," and "unsuccessful attempts to quit or cut down." 
TABLE 3. History and patterns of marijuana use reported by sample of adults ( $n=160)$ seeking treatment, Brazil, September 2003 to October 2004

\begin{tabular}{|c|c|c|}
\hline Category & No. & Percentage \\
\hline \multicolumn{3}{|c|}{ Characteristics of first time using marijuana } \\
\hline \multicolumn{3}{|l|}{ Place first used: } \\
\hline On the street & 60 & 37.5 \\
\hline At home & 44 & 28.0 \\
\hline \multicolumn{3}{|l|}{ With whom first used: } \\
\hline With friends & 125 & 78.1 \\
\hline \multicolumn{3}{|l|}{ Why first used? } \\
\hline Curiosity & 100 & 62.5 \\
\hline Social pressure & 45 & 28.1 \\
\hline \multicolumn{3}{|l|}{ Reasons for continuing to use: } \\
\hline Pleasure & 99 & 61.9 \\
\hline Social pressure & 26 & 16.3 \\
\hline Anxiety/low self-esteem & 16 & 10.0 \\
\hline \multicolumn{3}{|l|}{ Reasons for frequent use: } \\
\hline Anxiety & 15 & 9.4 \\
\hline Social pressure & 12 & 7.5 \\
\hline \multicolumn{3}{|l|}{ Typical form of use: } \\
\hline Joints & 158 & 98.8 \\
\hline \multicolumn{3}{|c|}{ Characteristics of use in last 12 months } \\
\hline \multicolumn{3}{|l|}{ With whom used: } \\
\hline Alone & 119 & 74.4 \\
\hline With friends & 21 & 13.1 \\
\hline Other & 20 & 12.5 \\
\hline \multicolumn{3}{|l|}{ Typical form of use: } \\
\hline Puffs & 82 & 51.3 \\
\hline Whole joint & 62 & 38.8 \\
\hline Various & 16 & 10.0 \\
\hline \multicolumn{3}{|l|}{ Frequency of use: } \\
\hline More than once a day & 80 & 50.0 \\
\hline Once a day & 55 & 34.4 \\
\hline 3 to 5 times a week & 23 & 14.4 \\
\hline \multicolumn{3}{|l|}{ Preferred time of the day: } \\
\hline 3rd quarter (6 p.m.-12 a.m.) & 141 & 88.1 \\
\hline \multicolumn{3}{|l|}{ Size of the joint: } \\
\hline Thin & 76 & 47.5 \\
\hline Medium & 65 & 40.6 \\
\hline Large & 15 & 9.4 \\
\hline \multicolumn{3}{|l|}{ Source of supply: } \\
\hline Buy & 143 & 89.9 \\
\hline Do not buy & 5 & 3.1 \\
\hline Varies (given, etc.) & 9 & 5.6 \\
\hline \multicolumn{3}{|l|}{ Where bought: } \\
\hline From a friend/acquaintance & 68 & 42.5 \\
\hline In a drug hangout & 53 & 33.1 \\
\hline Ordered by telephone & 17 & 10.6 \\
\hline From a dealer & 15 & 9.4 \\
\hline
\end{tabular}

These results show an association between consumption and the presence of specific symptoms, of which "tolerance" and "time spent doing marijuana-related activities" were most significant.

On a scale from 0 to 19 the mean number of problems was $9.91(\mathrm{SD}=$ $4.15)$, a result similar to that reported elsewhere $(26,27)$. The correlation between the mean number of problems lems. Table 6 shows the percentage of people reporting each of the problems, with the main one being "procrastination" (88.1\%) which corresponds to a study by Stephens et al. (26).

Table 6 also shows the associations between the two main variables that measure consumption (percentage of days smoked and mean number of joints smoked per day in the last 90 days) and each of the 19 problems from the Marijuana Problem Scale. We found a statistically significant correlation for both measures of consumption due to "legal problems" and to "lowered self-esteem." There was a partially statistically significant correlation (i.e., just one of the two measures: either percentage of days smoked or mean number of joints smoked per day in the last 90 days) for "problems between subject and friends," "miss days at work or miss classes," "medical problems," "financial difficulties," and "lower energy level."

These results suggest that the more cannabis the subjects consumed, the higher their chances of having legal problems and a poor self-image. Marijuana use also indicated problems with friends or concerning occupational, financial, and physical issues.

Table 7 describes the main abstinence symptoms reported, with the main one being "craving," followed by "restlessness," "nervousness," and "irritability." "Craving" was the only symptom described as severe; the others were generally described as mild to moderate.

In relation to use of alcohol and other drugs, the percentage of days subjects reported alcohol use in the 90 days prior to the baseline interview was $10.4 \%$, while for other drugs the value was less than $1 \%$. In terms of lifetime use, $98.8 \%$ had drunk alcoholic beverages, $87.3 \%$ had snorted cocaine, $76.9 \%$ had inhaled solvents, $75.7 \%$ had smoked tobacco, $57.2 \%$ had taken hallucinogens (primarily LSD and psilocybin or "magic" mushroom tea), $30.6 \%$ had smoked "crack," $24.3 \%$ had taken sedatives, $22.5 \%$ had used amphetamines, 22\% had used Ecstasy, and 9.8\% had used opiates. Use of other types of drugs was reported by $15.6 \%$ of the sample, the two most common being 
TABLE 4. History of abstinence and reduction of marijuana use and knowledge of drug as reported by sample of adults $(n=160)$ seeking treatment, Brazil, September 2003 to October 2004

\begin{tabular}{lcc}
\hline \multicolumn{1}{c}{ Variable } & No. & Percentage \\
\hline Subjects have abstained from using marijuana & 123 & 76.9 \\
Subjects have reduced consumption & 117 & 73.1 \\
Methods of reducing consumption (more than one choice is allowed): & & \\
$\quad$ Reduced no. of joints per day & 85 & 53.1 \\
Reduced no. of times per day & 53 & 33.5 \\
Reduced number of days smoked & 40 & 25.6 \\
Changed quarters (6-hour periods) when consumed & 30 & 19.1 \\
Subjects have never received treatment & 152 & 95 \\
What subjects know about marijuana: & & \\
"Something" & 70 & 43.8 \\
"A lot" & 47 & 29.4 \\
"A little" & 33 & 20.6 \\
Subjects want to know more about marijuana & 8 & 5.0 \\
Subjects want to know more about adverse effects of marijuana & 148 & 92.5 \\
\hline
\end{tabular}

mesclado (a mixture of marijuana and crack) and anticholinergics. Alcohol was the most commonly used substance apart from cannabis, with $89.6 \%$ of the sample having consumed it in the days before the interview, and $31.8 \%$ having had problems with alcohol at some point in life, although the frequency of its use was "occasional" (on weekends). Fewer than half of the subjects had used tobacco in the few days preceding the interview, whereas $66 \%$ reported problems due to smoking in life. Recent, "occasional" cocaine use was reported by $18.5 \%$ of the sample.

\section{DISCUSSION}

The sample's demographics follow a similar profile found in other studies

TABLE 5. Subjects from the total sample $(n=160)$ reporting marijuana dependence symptoms defined by DSM-III-R Checklist and correlations with consumption variables (percentage of days smoked and mean number of joints smoked per day in the last 90 days), Brazil, September 2003 to October 2004

\begin{tabular}{|c|c|c|c|c|c|}
\hline Marijuana dependence symptoms ${ }^{a}$ & $\begin{array}{c}\text { Subjects who } \\
\text { did not ("No") } \\
\text { and who did ("Yes") } \\
\text { report symptoms } \\
\text { No. (\%) }\end{array}$ & $\begin{array}{c}\text { Number of joints } \\
\text { smoked per day } \\
\text { Mean (SD) }\end{array}$ & $P$ & $\begin{array}{c}\text { Percentage } \\
\text { of days smoked } \\
\text { in the last } 90 \text { days }\end{array}$ & $P$ \\
\hline $\begin{array}{l}\text { Withdrawal as manifested by: } \\
\text { (a) Abstinence syndrome }\end{array}$ & $\begin{array}{l}\text { No: } 38(31.7) \\
\text { Yes: } 82(68.3)\end{array}$ & $\begin{array}{l}1.76(1.77) \\
1.95(1.68)\end{array}$ & 0.563 & $\begin{array}{l}85.1 \\
94.2\end{array}$ & $0.003^{c}$ \\
\hline $\begin{array}{l}\text { Tolerance as defined by: } \\
\text { (a) Need for markedly increased } \\
\text { amounts of substance to achieve } \\
\text { intoxication or desired effect }\end{array}$ & $\begin{array}{l}\text { No: } 78(63.4) \\
\text { Yes: } 45(36.6)\end{array}$ & $\begin{array}{l}1.48(1.31) \\
2.66(2.00)\end{array}$ & $0.000^{c}$ & $\begin{array}{l}88.7 \\
96.5\end{array}$ & $0.006^{c}$ \\
\hline $\begin{array}{l}\text { (b) Diminished effect with continued } \\
\text { use of same amount of substance }\end{array}$ & $\begin{array}{l}\text { No: } 53(44.5) \\
\text { Yes: } 66(55.5)\end{array}$ & $\begin{array}{l}1.39(1.27) \\
2.26(1.89)\end{array}$ & $0.005^{c}$ & $\begin{array}{l}87.8 \\
94.0\end{array}$ & $0.031^{c}$ \\
\hline $\begin{array}{l}\text { Considerable time spent buying, using, } \\
\text { or recovering from the effects }\end{array}$ & $\begin{array}{l}\text { No: } 47(38.2) \\
\text { Yes: } 76(61.8)\end{array}$ & $\begin{array}{l}1.57(1.43) \\
2.13(1.80)\end{array}$ & 0.078 & $\begin{array}{l}87.3 \\
94.2\end{array}$ & $0.016^{c}$ \\
\hline $\begin{array}{l}\text { Using takes up the time normally } \\
\text { spent on other important activities }\end{array}$ & $\begin{array}{l}\text { No: } 47(38.2) \\
\text { Yes: } 76(61.8)\end{array}$ & $\begin{array}{l}1.51(1.21) \\
2.17(1.89)\end{array}$ & $0.034^{c}$ & $\begin{array}{l}90.9 \\
91.9\end{array}$ & 0.704 \\
\hline $\begin{array}{l}\text { Using despite persistent or recurrent } \\
\text { psychological or physical problems }\end{array}$ & $\begin{array}{r}\text { No: } 21(17.1) \\
\text { Yes: } 102(82.9)\end{array}$ & $\begin{array}{l}1.65(1.67) \\
1.97(1.70)\end{array}$ & 0.434 & $\begin{array}{l}83.6 \\
93.2\end{array}$ & $0.010^{C}$ \\
\hline
\end{tabular}

a Symptoms as defined in the DSM-III-R Checklist (36).

b For dependence symptoms, sample size is from 119 to 123 .

${ }^{c} P<0.05$. 
TABLE 6. Subjects reporting marijuana-related problems according to the Marijuana Problems Scale and correlations with consumption variables (percentage of days smoked and mean number of joints smoked per day in the last 90 days), Brazil, September 2003 to October 2004

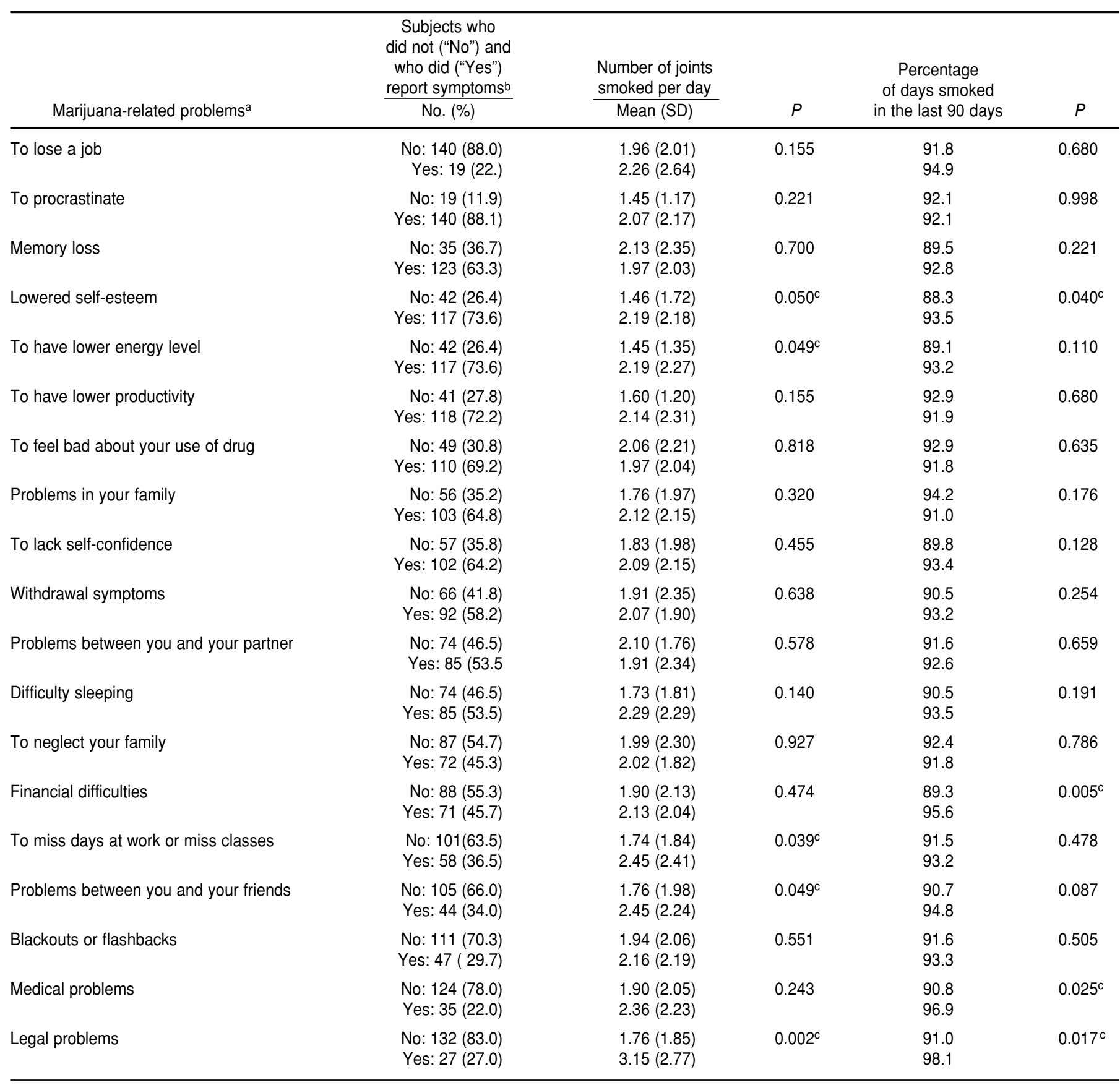

a Problems as defined in the Marijuana Problems Scale (26).

${ }^{b}$ For dependence symptoms, sample size is from 158 to 159.

c $P<0.05$.

$(26,28,38)$, namely, they are primarily male, single, white, with a mean age of 32 years. It is interesting to note that for clinical samples subjects are older than for prevalence studies of marijuana users. This piece of evidence leads us to conclude that it takes some years of regular marijuana use before an individual realizes its adverse effects.

In the Brazilian sample, marijuana use started at a mean of 16.44 years old. In the United States, studies report beginning use at a mean of 16.17 years old (25) and 14.7 years old (39); in Australian samples beginning marijuana use at 15 years old is reported (38). Daily use commenced later in the Brazilian sample (at a mean of 21 years old) compared with U.S. samples (regular use starting at 18.21 years old and problematic use at 26.86 years old) 
TABLE 7. Subjects from sample of marijuana users $(n=160)$ reporting severity of withdrawal symptoms as defined by the Marijuana Withdrawal Scale (37), Brazil, September 2003 to October 2004

\begin{tabular}{lcccc}
\hline Symptoms of marijuana withdrawal & None (\%) & Mild (\%) & Moderate (\%) & Severe (\%) \\
\hline Craving to smoke marijuana & 10.4 & 17.9 & 26.6 & 45.1 \\
Nervousness & 16.8 & 19.7 & 30.1 & 33.5 \\
Restlessness & 13.3 & 30.1 & 28.9 & 27.7 \\
Irritability & 23.1 & 15.0 & 37.0 & 24.9 \\
Sleep difficulty & 31.2 & 20.8 & 24.9 & 23.1 \\
Violent outbursts & 35.8 & 26.6 & 18.5 & 19.1 \\
Depressed mood & 26.0 & 28.9 & 27.2 & 17.9 \\
Strange dreams & 61.8 & 16.2 & 12.7 & 9.2 \\
Decreased appetite & 46.8 & 23.7 & 20.8 & 8.7 \\
Anger & 46.8 & 27.2 & 18.5 & 7.5 \\
Headaches & 61.0 & 17.4 & 14.5 & 7.0 \\
Sweating & 69.9 & 16.2 & 7.5 & 6.4 \\
Stomach pain & 79.8 & 10.4 & 7.5 & 2.3 \\
Nausea & 80.9 & 11.0 & 6.4 & 1.7 \\
Shakiness/trembling & 79.2 & 15.0 & 5.2 & 0.6 \\
\hline
\end{tabular}

(27), and Australian samples (regular use starting at 18 years old) (38). The age of initiation of use in the Brazilian sample is higher and the length of time between the initiation of use and problematic use of cannabis is longer (4 years) compared with the U.S. and Australian samples (2 and 3 years, respectively), which could indicate less risk of severity $(40,41)$.

Subjects in the U.S. and Australian samples tended to use the drug more times per day. It is difficult to make comparisons about this variable because marijuana smoked in Brazil might not have the same concentration as that smoked in the U.S. or Australia, and in Brazil the measure was in joints while in Australia it was in pipes. The other measures of use (percentage of days used in the last 90 days, and mean number of joints smoked) are very similar between Brazilian and other clinical populations. This is positive in the sense that treatment methods used elsewhere can be shared and adapted for use in Brazilian settings. On the other hand, the similarity to the U.S. and Australian samples is disquieting, because as a developing country there are fewer resources in Brazil, both human and financial, to combat the problem.

In spite of displaying a high prevalence of cocaine experimentation, the Brazilian sample seems to be a "pure" marijuana sample; following experimentation, the subjects had no major problematic use of other drugs $(24,26)$. In this sense, the sample does not reflect other epidemiological Brazilian data because our subjects tended to display a higher prevalence of drug use in general.

The history of use in this sample shows experimentation through $\mathrm{cu}-$ riosity but then a progression in use for pleasure. In contrast to research on protective and risk factors, social pressure in this particular sample is not the main reason, but ranks as the second reason for initiating and continuing the use of cannabis. In fact, most of the subjects reported that they smoked alone, contrary to the notion that marijuana is a "social" drug.

This was the first time in treatment for the majority of subjects in the Brazilian sample, although most had previously tried to stop on their own. This represents a marked difference from the U.S. and Australian subjects, who sought treatment more readily than Brazilians, possibly because they have access to specialized services.

Although our sample showed fewer dependence symptoms than those reported in other studies, the vast majority of subjects $(88.7 \%)$ met criteria for dependence, even though this was not an inclusion criterion for the study. The strong correlations between cannabis use and most dependence symptoms suggest that quantity and frequency of use might be important factors in reaching a diagnosis of dependence. Given that "tolerance" is an important symptom of dependence, it is worthwhile to encourage subjects who have experimented or are beginning to use marijuana frequently to stop before their consumption increases. In other words, "invest in prevention."

Regarding the severity of marijuanarelated problems, results for the Brazilian sample were similar to those reported in a U.S. study (27). The five most common problems mentioned were: procrastination, feeling bad about using, lower energy levels, memory loss, and lower productivity. The correlation between consumption and related problems underscores side-effects of consuming marijuana: the more consumed the more complications the subject might experience. From the 19 problems listed, "legal problems" and "lowered self-esteem" had the strongest correlation with consumption, suggesting that the consequences of marijuana use for this population are broad, ranging from psychological problems to social ones. Marijuana use also leads to problems with friends and occupational, financial, and physical problems.

These findings have implications about treatment for this population. The most valuable approach would include a multi-disciplinary team that can provide not only the psychological support to rebuild self-esteem and reinforce coping and social skills, but also professionals who can advise on legal and financial problems.

Cannabis use, even when it is problematic (as in the sample described here), does not necessarily disrupt normal activities such as maintaining employment or having a relationship. Consequently, it is difficult to bring this population to treatment and they seek help only when they "hit rock bottom." This pattern is similar to that of cigarette smokers, who also take a long time to realize the harm of tobacco. The severity of withdrawal from marijuana has been shown to be comparable to withdrawal from tobacco (37). 


\section{Limitations}

To the best of our knowledge, this is the first study involving a clinical sample of marijuana users in Brazil. Because the sample was selected for a randomized controlled trial, many of the assumptions made could not be generalized for the Brazilian population of cannabis users. Also, the subjects were recruited primarily through media (television programs and newspapers) that tend to be more accessible to a part of the population that is more financially and socially stable, another limitation of the study. The information acquired was self-reported, based on the subjects' memories, and is therefore impossible to confirm. A lon- gitudinal study of such a sample would be useful.

\section{CONCLUSION}

The subjects in the sample have patterns of marijuana use that are comparable to those reported worldwide. The profile of users is closer to that of subjects in the U.S. study (25-27) than to subjects in the Australian study (38). Subjects who abuse marijuana do suffer from both adverse physical and psychological effects. As consumption increases, marijuana users are at greater risk of suffering from dependence symptoms and problems related to marijuana use.
This study confirms that marijuana can harm those who use it, and individuals with cannabis problems might seek specialized treatment. Based on the characteristics of this sample, treatment measures should be further explored, allowing specific treatment to be devised. More extensive epidemiological studies should be conducted to determine the extent of marijuana use in the Brazilian population as well as the number of users who are seeking treatment.

Acknowledgments. This study was funded by a grant from Fundação de Amparo à Pesquisa do Estado de São Paulo (FAPESP), a government funding agency.

\section{REFERENCES}

1. Hall W, Solowij N. Adverse effects of cannabis. Lancet. 1998;352(9140):1611-6.

2. Hall W, Johnston L, Donnelly N. The epidemiology of cannabis use and its consequences. In: Kalant H, Corrigall W, Hall W, Smart R, eds. The health effects of cannabis. Toronto: Centre for Addiction and Mental Health; 1999. Pp. 71-125.

3. United Nations Office on Drugs and Crime. World drug report 2007. [Internet site]. Available from: http://www.unodc.org/unodc/ en/data-and-analysis/WDR-2007.html. Accessed 20 October 2007.

4. U.S. Department of Health and Human Services, Substance Abuse and Mental Health Services Administration, Office of Applied Studies. National survey on drug use and health-2004. [Internet site]. http://www. oas.samhsa.gov/NSDUH/2k4NSDUH/2k4 results $/ 2 \mathrm{k} 4$ results.htm. Accessed 20 October 2007.

5. Anthony JC, Warner LA, Kessler RC. Comparative epidemiology of dependence on tobacco, alcohol, controlled substances and inhabitants: basic findings from the National Comorbidity Study. Exp Clin Psychopharmacol. 1994;2;244-68.

6. Hall W, Degenhardt L. Prevalence and correlates of cannabis use in developed and developing countries. Curr Opin Psychiatry. 2007;20(4):393-7.

7. Hall W, Solowij N, Lemon J. The health and psychological consequences of cannabis use. Canberra: Australian Government Publication Service; 1994. (National Drug Strategy Monograph Series No. 25).

8. Kandel D, Chen K, Warner LA, Kessler RC, Grant B. Prevalence and demographic correlates of symptoms of last year dependence on alcohol, nicotine, marijuana and cocaine in the
U.S. population. Drug Alcohol Depend. 1997;44(1):11-29.

9. Fergusson DM, Horwood LJ. Does cannabis use encourage other forms of illicit drug use? Addiction. 2000;95(4):505-20.

10. Galduróz J, Dias JC. Epidemiologia do uso da maconha no Brasil. In: Associação Brasileira de Psiquiatria. Revisão científica: maconha e saúde mental, 10 June 2005. [Internet site]. Available at: http://www.abpbrasil.org.br/ departamentos/coordenadores/coordenador/ noticias $/$ ?not $=79 \&$ dep $=62$. Accessed on 6 November 2007.

11. Galduróz JCF, Noto AR, Fonseca A, Carlini EA. V Levantamento nacional sobre o consumo de drogas psicotrópicas entre estudantes do ensino fundamental e médio da rede pública de ensino nas 27 capitais brasileiras, 2004. São Paulo: Universidade Federal de São Paulo, Centro Brasileiro de Informações sobre Drogas Psicotrópicas (UNIFESP/CEBRID); 2005. Available online at: http://www.cebrid.epm. br/levantamento_brasil2/index.htm.

12. Chile, Ministerio del Interior, Consejo Nacional para el Control de Estupefacientes (CONACE). Quinto informe anual sobre la situación de drogas en Chile. Santiago: CONACE; 2005. Available at: http://www. conacedrogas.cl/inicio/pdf/Obser_ok.pdf. Accessed 9 October 2006.

13. Organization of American States, InterAmerican Drug Abuse Control Commission (OAS/CICAD). Comparative report on nationwide school surveys in seven countries: El Salvador, Guatemala, Nicaragua, Panama, Paraguay, Dominican Republic, and Uruguay, 2003. Washington, D.C.: OAS/CICAD; 2004. Available at: http://www.cicad.oas. org/oid/Estadisticas/resumen2004/SIDUC/ INFORME $\% 20$ COMPARATIVO $\% 207 \% 20$
PAISES\%20ENG\%20r1.pdf. Accessed 9 October 2006.

14. European Monitoring Centre for Drugs and Drug Addiction (EMCDDA). Cannabis; Introduction: the changing picture of cannabis use in Europe. [Internet site]. Available from http:// www.emcdda.europa.eu/publications / online/ar2007/en/cannabis. Accessed 1 April 2008.

15. U.S. National Institutes of Health, National Institute on Drug Abuse (NIDA). NIDA infofacts: high school and youth trends. [Internet site]. Available from http://www.drugabuse. gov/infofax/hsyouthtrends.html. Accessed 9 October 2006.

16. Carlini EA, Galduróz JCF, Noto AR, Nappo SA. I levantamento domiciliar sobre o uso de drogas psicotrópicas no Brasil, 2001. São Paulo: Universidade Federal de São Paulo, Centro Brasileiro de Informações sobre Drogas Psicotrópicas (UNIFESP/CEBRID); 2002. Available online at: http:/ /www.unifesp.br/ dpsicobio/cebrid/levantamento_brasil/parte _1.pdf

17. Rodríguez Ospina E. Estudio nacional sobre consumo de sustancias psicoactivas en Colombia 1996. Bogotá: Editorial Carrera 7a Ltda; 1997.

18. McRae AL, Budney AJ, Brady KT. Treatment of marijuana dependence: a review of the literature. J Subst Abuse Treat. 2003;24(4):369-76.

19. Murray RM, Morrison PD, Henquet C, Di Forti M. Cannabis, the mind and society: the hash realities. Nat Rev Neurosci. 2007;8(11): 885-95.

20. Hall W, Babor T. Cannabis use and public health: assessing the burden [editorial]. Addiction. 2000; 95(4):485-90.

21. Copeland J, Indig D. Patterns and correlates of treatment: Findings of the 2000-2001 NSW 
minimum dataset of clients of alcohol and other drug treatment treatment. Drug Alcohol Rev. 2004;23(2):185-94.

22. European Monitoring Centre for Drugs and Drug Addiction (EMCDDA). Annual report 2004: the state of the drugs problem in the European Union and Norway. Lisbon: EMCDDA; 2004. Available online from: http://ar2004.emcdda.europa.eu/download/ ar2004en. pdf

23. Urbanoski KA, Strike CJ, Rush BR. Individuals seeking treatment for cannabis-related problems in Ontario: demographic and treatment profile. Eur Addict Res. 2005;11(3): 115-23.

24. Stephens RS, Roffman RA. Adult marijuana dependence. In: Baer JS, Marlatt GA, McMahon RJ, eds. Addictive behaviors across the lifespan: prevention, treatment and policy issues. Newbury Park, California: Sage Publications; 1993. Pp. 202-18.

25. Stephens RS, Roffman RA, Curtin L. Treating adult marijuana dependence: a test of the relapse prevention model. J Consult Clin Psychol. 1994;62(1):92-9.

26. Stephens RS, Roffman RA, Curtin L. Comparison of extended versus brief treatments for marijuana use. J Consult Clin Psychol. 2000; 68(5):898-908.

27. Stephens R, Babor T, Kadden R, Miller M; Marijuana Treatment Project Research Group. The Marijuana Treatment Project: rationale, design and participant characteristics. Addiction. 2002;97(Suppl 1):109-24.

28. Budney AJ, Higgins ST, Radonovich KJ, Novy PL. Adding voucher-based incentives to cop- ing skills and motivational enhancement improves outcomes during treatment for marijuana dependence. J Consult Clin Psychol. 2000;68(6):1051-61.

29. Copeland J, Swift W, Rees V. Clinical profile of participants in a brief intervention program for cannabis use disorder. J Subst Abuse Treat. 2001;20(1):45-52.

30. Lang E, Engelander M, Brooke T. Report of an integrated brief intervention with self-defined problem cannabis users. J Subst Abuse Treat. 2000;19(2):111-6.

31. Jungerman FS, Andreoni S, Laranjeira R. Short term impact of the same intensity but different duration interventions for cannabis users. Drug Alcohol Depend. 2007;90(1-2):120-7.

32. Quintana, MI. Validade do composite international diagnostic interview (CIDI/OMS) versão 2.1 em serviços de saúde mental no Brasil. São Paulo; s.n; 2005. 173 pp. Apresentada a Universidade Federal de São Paulo. Escola Paulista de Medicina. Curso de Psiquiatria para obtenção do grau de Doutor.

33. Wender P. Wender Utah rating scale: Attention deficit hyperactivity disorder in adults. New York: Oxford University Press; 1995.

34. Sobell LC, Sobell MB. Time-line follow back: a technique for assessing self-reported alcohol consumption. In: Allen JP, Litten RZ, eds. Measuring alcohol consumption: psychosocial and biochemical methods. Totawa, New Jersey: Humana Press; 1992. Pp. 41-72.

35. Hudziak JJ, Helzer JE, Wetzel MW, Kessel KB, McGee B, Janca A, et al. The use of the DSM-III-R Checklist for initial diagnostic as- sessment. Compr Psychiatry. 1993;34(6): 375-83.

36. Budney AJ, Novy PL, Hughes JR. Marijuana withdrawal among adults seeking treatment or marijuana dependence. Addiction. 1999; 94(9):1311-22.

37. Budney AJ, Hughes JR, Moore BA, Vandrey $R$. Review of the validity and significance of cannabis withdrawal syndrome. Am J Psychiatry. 2004;161(11):1967-77.

38. Copeland J, Swift W, Roffman R, Stephens R. A randomized controlled trial of brief cognitivebehavioral interventions for cannabis use disorder. J Subst Abuse Treat. 2001;21(2): 55-64.

39. Budney AJ, Moore BA, Rocha HL, Higgins ST. Clinical trial of abstinence-based vouchers and cognitive-behavioral therapy for cannabis dependence. J Consult Clin Psychol. 2006; 74(2):307-16

40. Fergusson DM, Horwood LJ, Lynskey MT Madden PA. Early reactions to cannabis predict later dependence. Arch Gen Psychiatry. 2003;60(10):1033-9.

41. Ridenour TA, Maldonado-Molina M, Compton WM, Spitznagel EL, Cottler LB. Factors associated with the transition from abuse to dependence among substance abusers: implications for a measure of addictive liability. Drug Alcohol Depend. 2005;80(1);1-14.

Manuscript received on 9 October 2006. Revised version accepted for publication on 7 January 2008.

RESUMEN Objetivos. Describir una muestra de 160 adultos seleccionados para participar en un ensayo aleatorizado controlado, realizado en una clínica ambulatoria especializada para consumidores de marihuana en Brasil. Se asoció el consumo de marihuana con varias medidas relacionadas con este hábito y se comparó con otras muestras.

Características de los fumadores de marihuana que buscan tratamiento en São Paulo, Brasil

Métodos. Se empleó la Entrevista Diagnóstica Internacional Compuesta (CIDI) y la Escala de Valoración de Wender Utah para las entrevistas de tamizaje y la obtención de datos demográficos, y el Índice de Intensidad de la Adicción (ASI), la Línea Cronológica Retrospectiva (TLFB), la Escala de Abandono de la Marihuana, la Escala de Problemas por Marihuana y la lista de comprobación para la dependencia de la marihuana del Manual Diagnóstico y Estadístico de Trastornos Mentales (DSM-III-R). Resultados. La mayoría de los participantes eran hombres blancos solteros; en promedio, la edad fue de 32,3 años y el nivel de escolarización de 15,6 años; $61,6 \%$ trabajaba. Como promedio, esta cohorte comenzó a fumar marihuana a una edad de 16,5 años y llegó a consumirla diariamente a los 21. Los participantes habían consumido marihuana durante 15 años y la consumieron $92,2 \%$ de los 90 días previos a la encuesta, con un consumo diario medio en ese lapso de 1,99 cigarrillos de marihuana. Miembros del grupo habían experimentado con otras drogas, principalmente cocaína. Conclusiones. Los consumidores de marihuana estudiados se ajustan a los perfiles encontrados en otras investigaciones similares, aunque manifestaron menos síntomas de dependencia. En los programas para consumidores de estupefacientes se debe considerar a los consumidores de marihuana de manera independiente, ya que necesitan atención y tratamiento específicos. Se deben emprender estudios epidemiológicos más amplios para determinar la magnitud del consumo de marihuana en la población brasileña.

Palabras clave Marihuana, abuso de marihuana, dependencia a la marihuana, centros de rehabilitación de drogas, Brasil. 